\title{
Refinement of Solidification Microstructure and Austenite Grain by Fine Inclusion Particles
}

\author{
Hideaki SUITO, Hiroki OHTA and Shuhei MORIOKA \\ Institute for Multidisciplinary Research for Advanced Materials, Tohoku University, Katahira, Aoba-ku, Sendai, Miyagi $980-8577$ \\ Japan.
}

(Received on October 31, 2005; accepted on February 6, 2006)

\begin{abstract}
The effect of deoxidation products of $\mathrm{Ce}_{2} \mathrm{O}_{3}, \mathrm{ZrO}_{2}$ and $\mathrm{MgO}$ particles on solidification microstructure has been studied in $\mathrm{Fe}-10 \mathrm{mass} \% \mathrm{Ni}, \mathrm{Fe}-0.20$ mass \% C-0.02mass\% $\mathrm{P}$ and $\mathrm{Fe}-0.50 \mathrm{mass} \% \mathrm{C}-1 \mathrm{mass} \% \mathrm{Mn}$ alloys. The degree of the equiaxed crystallization is explained by the lattice misfit parameter between $\gamma($ or $\delta$ )-Fe and oxide. The single-phase solidification microstructure of $\mathrm{Fe}-10 \mathrm{mass} \% \mathrm{Ni}$ and $\mathrm{Fe}-0.50 \mathrm{mass} \% \mathrm{C}-$ $1 \mathrm{mass} \% \mathrm{Mn}$ alloys is well related to austenite grain boundaries under the inhibition of grain growth by pinning. The correspondence between solidification structure and initial austenite grain has been studied in two-phases solidification of Fe- 0.15 (or 0.30 ) mass $\% \mathrm{C}-1$ mass $\% \mathrm{Mn}-1$ mass $\% \mathrm{Ni}$ alloy. The $\gamma$-grain size decreases with decreasing the lattice misfit parameter between $\gamma$-Fe and oxide and increases with decreasing the Zener pinning force. The number of $\gamma$-grains to that of primary $\delta$-grains per unit area in a cross section increases with decreasing the aforementioned lattice misfit parameter, indicating that more than one nucleation event per $\delta$-grain occurs at $\delta$-ferrite grain boundary during $\delta$ to $\gamma$ transformation.
\end{abstract}

KEY WORDS: solidification; $\delta$ - $\gamma$ transformation; Zener pinning force; grain growth; deoxidation; inclusion.

\section{Introduction}

In low alloy steel weld metals the austenite grains are usually finer than the $\delta$-ferrite columnar grain boundaries during $\delta$ to $\gamma$ transformation. ${ }^{1)}$ However, if the austenite is bounded by an orientation relationship with the $\delta$-ferrite, the austenite cannot grow across the primary $\delta$-ferrite solidification boundaries. It is reported ${ }^{2)}$ that in the presence of $\mathrm{Al}_{2} \mathrm{O}_{3}$ inclusions, nucleation of austenite phase becomes energetically more favorable and thus steel solidifies directly as austenite in interdendritic liquid.

In this review the refinement of solidification microstructure and the equiaxed crystallization by using various deoxidation products are first discussed as a function of inclusion number and composition, and solute content in an $\mathrm{Fe}-10 \mathrm{mass} \% \mathrm{Ni}$ or $\mathrm{Fe}-0.50 \mathrm{mass} \% \mathrm{C}$. Secondly, the correspondence between solidification microstructure and initial austenite grain is demonstrated for a single-phase $(\mathrm{Fe}-10 \mathrm{mass} \% \mathrm{Ni}$ and $\mathrm{Fe}-0.50 \mathrm{mass} \% \mathrm{C})$ and two-phases ( $\mathrm{Fe}-0.15$ and $0.30 \mathrm{mass} \% \mathrm{C}$ ) solidification alloys, focusing on the effects of oxide particles on the heterogeneous nucleation of $\delta$ to $\gamma$ transformation and the austenite grain growth inhibition.

\section{Experimental}

An $\mathrm{Fe}-10 \mathrm{mass} \% \mathrm{Ni}$ alloy $(70 \mathrm{~g})$ containing the initial oxygen content of 80 to 120 mass ppm was deoxidized with an $\mathrm{Fe}-10 \mathrm{mass} \% M(M=\mathrm{Ti}, \mathrm{Zr}$ and $\mathrm{Ce})$ and $\mathrm{Ni}-10 \mathrm{mass} \% \mathrm{Mg}$ alloys at $1600^{\circ} \mathrm{C}$ in an $\mathrm{Al}_{2} \mathrm{O}_{3}$ crucible using an induction furnace $(100 \mathrm{kHz}) .(\%$ and ppm represent mass $\%$ and mass ppm, respectively, hereinafter.) A melt was cooled to $1400^{\circ} \mathrm{C}$ at $50 \mathrm{~K} \cdot \mathrm{min}^{-1}$, followed by rapid quenching. The solidification structure was observed after etching in an Oberhöffer solution. The austenite grain size was measured after etching in a saturated picric acid solution. More details are given elsewhere. ${ }^{3,4)}$

An Fe-C (0.15 to $0.50 \%)$ alloy ( $70 \mathrm{~g})$ containing $1 \% \mathrm{Mn}$ whose initial oxygen content was 80 to $100 \mathrm{ppm}$ was deoxidized with an $\mathrm{Fe}-10 \% M(M=\mathrm{Ti}, \mathrm{Al}, \mathrm{Zr}$ and $\mathrm{Ce})$ and $\mathrm{Ni}-10 \% M(M=\mathrm{Ca}$ and $\mathrm{Mg})$ alloys at $1600^{\circ} \mathrm{C}$ in an $\mathrm{Al}_{2} \mathrm{O}_{3}$ crucible using an induction furnace $(100 \mathrm{kHz})$. A melt was cooled to the respective temperatures at $50 \mathrm{~K} \cdot \mathrm{min}^{-1}$, followed by rapid quenching. The shape of a quenched sample was the frustum with the top $(28 \mathrm{~mm})$ and bottom diameters $(16 \mathrm{~mm})$ and height $(20 \mathrm{~mm})$. The vertically sliced sample was used for the observation of solidification structure and austenite grain. The solidification structure was observed after etching in an Oberhöffer solution and/or a saturated picric acid and $\mathrm{CuCl}_{2}$ solution. The austenite grain size was measured after etching in $2 \%$-Nital or a saturated picric acid and $\mathrm{CuCl}_{2}$ solution. The mean primary arm length, $\bar{l}_{1}$, mean primary arm spacing, $\bar{\lambda}_{1}$, and density of dendrite were measured from solidification structure etched in an Oberhöffer solution and/or a saturated picric acid and $\mathrm{CuCl}_{2}$ solution. The observation area was about $200 \mathrm{~mm}^{2}$, which corresponded to the half of the cross section area of vertically sliced sample. The observation number of dendrite was about 20 to 50 . More details are given elsewhere. ${ }^{5,6)}$ The method of the particle size measurement is described elsewhere. ${ }^{7)}$ 
Table 1. Chemical composition and particle characteristics in $\mathrm{Fe}-0.15 \sim 0.50 \% \mathrm{C}$ and $\mathrm{Fe}-10 \% \mathrm{Ni}$ alloys.

\begin{tabular}{|c|c|c|c|c|c|c|c|c|c|}
\hline \multirow{2}{*}{$\begin{array}{l}\text { Exp. } \\
\text { No. }\end{array}$} & \multirow{2}{*}{ Deoxidant } & Q.T. & $\bar{D}_{\mathrm{A}}$ & $\bar{d}_{\mathrm{A}}$ & $N_{\mathrm{A}}$ & $f_{\mathrm{V}}$ & insol M & sol M. & $M$ \\
\hline & & $\left({ }^{\circ} \mathrm{C}\right)$ & $(\mu \mathrm{m})$ & $(\mu \mathrm{m})$ & $\left(\mathrm{mm}^{-2}\right)$ & $\times 10^{-4}$ & \multicolumn{2}{|c|}{ (ppm) } & \\
\hline \multicolumn{10}{|c|}{ Fe- $0.15 \% \mathrm{C}-1 \% \mathrm{Mn}-1 \% \mathrm{Ni}$ alloy } \\
\hline 1 & without & 1470 & 1800 & 3.28 & 41 & 0.30 & 8 & 4 & $\mathrm{Al}$ \\
\hline 2 & $\mathrm{Ce}$ & 1470 & 530 & 0.79 & 525 & 3.68 & 278 & 18 & $\mathrm{Ce}$ \\
\hline 3 & $\begin{array}{l}\mathrm{Mg} \\
\mathrm{Mg}\end{array}$ & 1500 & - & - & - & 1.43 & 40 & 35 & $\mathrm{Mg}$ \\
\hline 4 & & 1470 & 934 & 1.10 & 494 & 1.43 & 40 & 59 & $\mathrm{Mg}$ \\
\hline 5 & $\mathrm{Ti} / \mathrm{Mg}$ & 1470 & 701 & 0.83 & 1306 & 2.44 & 68 & 35 & $\mathrm{Mg}$ \\
\hline 6 & $\mathrm{Ti}$ & 1500 & - & - & - & 0.29 & 12 & 217 & $\mathrm{Ti}$ \\
\hline 7 & Ti & 1470 & 260 & 0.64 & 185 & 1.62 & 63 & 248 & $\mathrm{Ti}$ \\
\hline 8 & $\mathrm{Zr}$ & 1500 & - & - & - & 3.85 & 221 & 24 & $\mathrm{Zr}$ \\
\hline 9 & $\mathrm{Zr}$ & 1470 & 790 & 0.53 & 792 & 4.32 & 250 & 24 & $\mathrm{Zr}$ \\
\hline 10 & $\mathrm{Ca}$ & 1500 & - & - & - & 1.46 & 23 & 17 & $\mathrm{Ca}$ \\
\hline 11 & $\mathrm{Ca}$ & 1470 & 2000 & 0.90 & 535 & 1.00 & 32 & 4 & $\mathrm{Ca}$ \\
\hline
\end{tabular}

\begin{tabular}{rrrrrrrrrr}
12 & \multicolumn{8}{c}{ Fe-0.20\%C-0.02\% alloy } \\
13 & $\mathrm{Mg}$ & 1400 & 541 & 1.30 & 321 & 1.35 & 32 & 2 & $\mathrm{Mg}$ \\
14 & $\mathrm{Mg}$ & 1400 & 1051 & 1.02 & 634 & 1.78 & 50 & 50 & $\mathrm{Mg}$ \\
& & 1400 & 1181 & 0.60 & 530 & 1.06 & 30 & 275 & $\mathrm{Mg}$ \\
15 & $\mathrm{Zr}$ & 1400 & 225 & 2.38 & 248 & 3.94 & 205 & 23 & $\mathrm{Zr}$ \\
16 & $\mathrm{Zr}$ & 1400 & 316 & 1.49 & 212 & 2.19 & 115 & 1 & $\mathrm{Zr}$ \\
17 & $\mathrm{Zr}$ & 1400 & 356 & 1.94 & 238 & 5.26 & 305 & 2 & $\mathrm{Zr}$ \\
18 & $\mathrm{Zr}$ & 1400 & 1038 & 2.33 & 1435 & 125 & 7251 & 81 & $\mathrm{Zr}$ \\
& & & & & & & & & \\
19 & $\mathrm{Ce}$ & 1400 & 208 & 2.20 & 156 & 1.60 & 120 & 711 & $\mathrm{Ce}$ \\
20 & $\mathrm{Ce}$ & 1400 & 323 & 2.08 & 81 & 0.84 & 63 & 244 & $\mathrm{Ce}$ \\
21 & $\mathrm{Ce}$ & 1400 & 558 & 2.05 & 47 & 0.44 & 33 & 163 & $\mathrm{Ce}$ \\
22 & $\mathrm{Ce}$ & 1400 & 275 & 2.13 & 135 & 1.06 & 80 & 536 & $\mathrm{Ce}$ \\
23 & $\mathrm{Ce}$ & 1400 & 393 & 2.11 & 95 & 0.92 & 69 & 227 & $\mathrm{Ce}$ \\
24 & $\mathrm{Ce}$ & 1400 & 820 & 2.18 & 57 & 0.61 & 46 & 142 & $\mathrm{Ce}$
\end{tabular}

\begin{tabular}{cccccccccc}
\multicolumn{8}{c}{ Fe-0.30\%C-1\%Mn-1\%Ni alloy } \\
25 & $\mathrm{Ce}$ & 1460 & 353 & 0.98 & 720 & 2.15 & 163 & 11 & $\mathrm{Ce}$ \\
26 & $\mathrm{Mg}$ & 1460 & 915 & 1.14 & 514 & 1.54 & 43 & 10 & $\mathrm{Mg}$ \\
27 & $\mathrm{Ti}$ & 1460 & 576 & 0.97 & 268 & 1.22 & 48 & 35 & $\mathrm{Ti}$ \\
28 & $\mathrm{Zr}$ & 1460 & - & 0.80 & 206 & 3.40 & 197 & 7 & $\mathrm{Zr}$
\end{tabular}

\begin{tabular}{|c|c|c|c|c|c|c|c|c|c|}
\hline \multicolumn{10}{|c|}{ Fe- $0.50 \% \mathrm{C}-1 \% \mathrm{Mn}$ alloy } \\
\hline 29 & without & 1200 & 885 & 0.62 & 82 & 0.47 & 13 & $<1$ & $\mathrm{Al}$ \\
\hline 30 & $\mathrm{Zr}$ & 1200 & 330 & 0.90 & 967 & 2.61 & 150 & 2 & $\mathrm{Zr}$ \\
\hline 31 & $\mathrm{Ce}$ & 1200 & 720 & 0.94 & 1039 & 0.51 & 39 & 114 & $\mathrm{Ce}$ \\
\hline 32 & $\mathrm{Mg}$ & 1200 & 1800 & 1.08 & 905 & 1.49 & 42 & 91 & $\mathrm{Mg}$ \\
\hline \multicolumn{10}{|c|}{$\mathrm{Fe}-10 \% \mathrm{Ni}$ alloy } \\
\hline 33 & $\mathrm{Ce}$ & 1400 & 182 & 1.26 & 311 & 7.08 & 535 & 391 & $\mathrm{Ce}$ \\
\hline $34^{*}$ & $\mathrm{Ce}$ & 1400 & 172 & 1.05 & 375 & 2.64 & 199 & 490 & $\mathrm{Ce}$ \\
\hline $35^{* *}$ & $\mathrm{Ce}$ & 1400 & 202 & 1.59 & 203 & 2.26 & 171 & 229 & $\mathrm{Ce}$ \\
\hline 36 & $\mathrm{Ce}$ & 1400 & 433 & 1.35 & 73 & 4.30 & 325 & 2 & $\mathrm{Ce}$ \\
\hline 37 & $\mathrm{Mg}$ & 1400 & 903 & 0.47 & 658 & 4.26 & 119 & 105 & $\mathrm{Mg}$ \\
\hline 38 & $\mathrm{Mg}$ & 1400 & 1230 & 0.51 & 738 & 5.08 & 142 & 280 & $\mathrm{Mg}$ \\
\hline $39^{*}$ & $\mathrm{Mg}$ & 1400 & 688 & 0.83 & 432 & 2.76 & 77 & 31 & $\mathrm{Mg}$ \\
\hline $40^{* *}$ & $\mathrm{Mg}$ & 1400 & 801 & 1.20 & 265 & 2.61 & 73 & $<1$ & $\mathrm{Mg}$ \\
\hline $41^{* * *}$ & $\mathrm{Mg}$ & 1400 & 552 & 1.58 & 124 & 1.68 & 47 & 1 & $\mathrm{Mg}$ \\
\hline $42^{*}$ & $\mathrm{Mg}$ & 1400 & 753 & 0.65 & 738 & 1.86 & 52 & 53 & $\mathrm{Mg}$ \\
\hline $43^{* *}$ & $\mathrm{Mg}$ & 1400 & 477 & 0.74 & 335 & 1.86 & 52 & 56 & $\mathrm{Mg}$ \\
\hline 44 & $\mathrm{Zr}$ & 1400 & 153 & 1.05 & 144 & 4.73 & 272 & 263 & $\mathrm{Zr}$ \\
\hline $45^{* *}$ & $\mathrm{Zr}$ & 1400 & 318 & 1.25 & 134 & 9.14 & 525 & 148 & $\mathrm{Zr}$ \\
\hline $46^{* * *}$ & $\mathrm{Zr}$ & 1400 & 382 & 1.37 & 109 & 3.34 & 192 & 118 & $\mathrm{Zr}$ \\
\hline 47 & $\mathrm{Zr}$ & 1400 & 110 & 1.12 & 342 & 16.37 & 941 & 299 & $\mathrm{Zr}$ \\
\hline 48 & $\mathrm{Zr}$ & 1400 & 117 & 1.12 & 481 & 8.53 & 490 & 570 & $\mathrm{Zr}$ \\
\hline 49 & $\mathrm{Zr}$ & 1400 & 93 & 0.97 & 492 & 11.24 & 646 & 1080 & $\mathrm{Zr}$ \\
\hline
\end{tabular}

Q.T.: Temperature in water quenching

$*, * * * * *: 5,30$ and 60 min holding times at $1600{ }^{\circ} \mathrm{C}$

$-:$ not analyzed

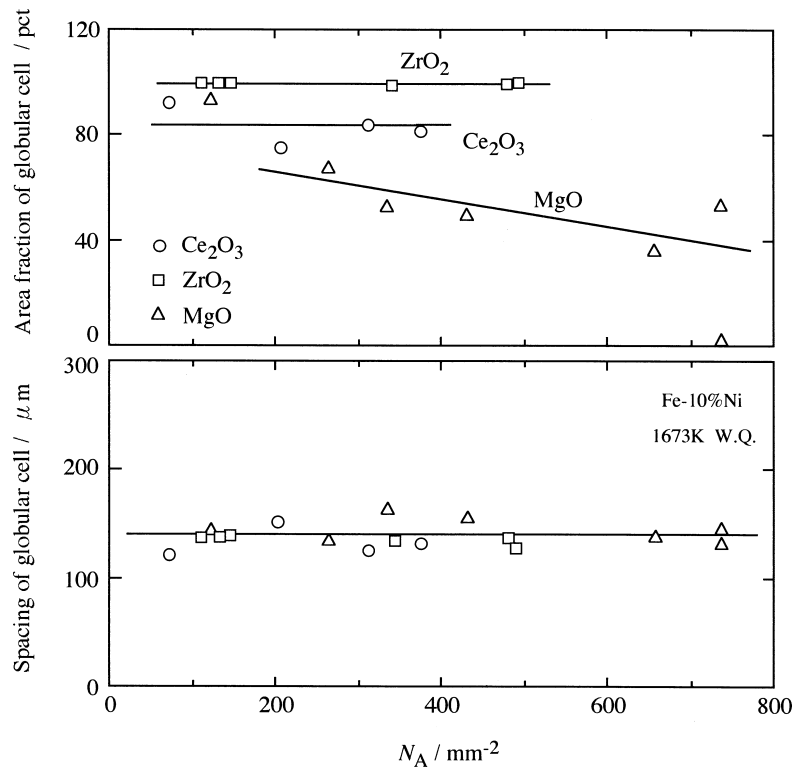

Fig. 1. Solidification microstructure in $\mathrm{Fe}-10 \% \mathrm{Ni}$ alloy deoxidized with $\mathrm{Ce}, \mathrm{Zr}$ or $\mathrm{Mg}$ at $1873 \mathrm{~K}$.

\section{Results}

The results for an $\mathrm{Fe}-10 \% \mathrm{Ni}$ alloy deoxidized with $\mathrm{Zr}$, $\mathrm{Mg}$ and $\mathrm{Ce}$ which are reported in previous study ${ }^{3,4)}$ are used in this study. The additional experimental results are given in Table 1, where quenching temperature, Q.T., average austenite grain size, $\bar{D}_{\mathrm{A}}$, particle diameter in cross section, $\bar{d}_{\mathrm{A}}$, particle number per unit volume, $N_{\mathrm{A}}$, and volume fraction of particle, $f_{\mathrm{V}}$, are summarized. The previous results ${ }^{5,6)}$ for an $\mathrm{Fe}-0.20 \% \mathrm{C}-0.02 \% \mathrm{P}$ alloy deoxidized with $\mathrm{Ce}$ are used in the present discussion. The $f_{\mathrm{V}}$ values are obtained from the chemically analyzed values for insol. $M$ by using the method described elsewhere. ${ }^{7)}$ The experimental results for $\mathrm{Fe}-0.15,0.20,0.30$ and $0.50 \% \mathrm{C}$ alloy are summarized in Table 1.

\section{Discussion}

\subsection{Refinement of Solidification Microstructure}

\subsubsection{Primary $\gamma$-phase Solidification}

The effects of the number of primary deoxidation particles on area fraction of equiaxed crystals and their size have been studied in the experiments where an $\mathrm{Fe}-10 \mathrm{mass} \% \mathrm{Ni}$ alloy with $\gamma$-phase solidification was deoxidized with $\mathrm{Ce}$, $\mathrm{Zr}$ or $\mathrm{Mg}$ at $1600^{\circ} \mathrm{C}$ and cooled to $1400^{\circ} \mathrm{C}$ at $50 \mathrm{~K} \cdot \mathrm{min}^{-1}$, followed by rapid quenching. The solidification microstructure in this alloy consists of columnar dendrite and globular cell. ${ }^{3,8)}$ In Fig. 1, the area fraction of globular cell and its size are plotted against the number of oxide particles per unit area, $N_{\mathrm{A}}$, in a cross section. It is seen from the upper diagram that the area fraction of globular cell for a given $N_{\mathrm{A}}$ increases in the order $\mathrm{MgO}, \mathrm{Ce}_{2} \mathrm{O}_{3}$ and $\mathrm{ZrO}_{2}$ which is in good agreement with that for the lattice misfit between $\gamma$-Fe and oxide, ${ }^{9)}$ as shown in the upper diagram of Fig. 2. The finding that the area fraction of globular cell for $\mathrm{Mg}$ deoxidation decreases with an increase of the number of $\mathrm{MgO}$ particles can be explained by the fact that dissolved $\mathrm{Mg}$ affects the development of columnar dendrite.

The result shown in the lower diagram of Fig. 1 indicates 


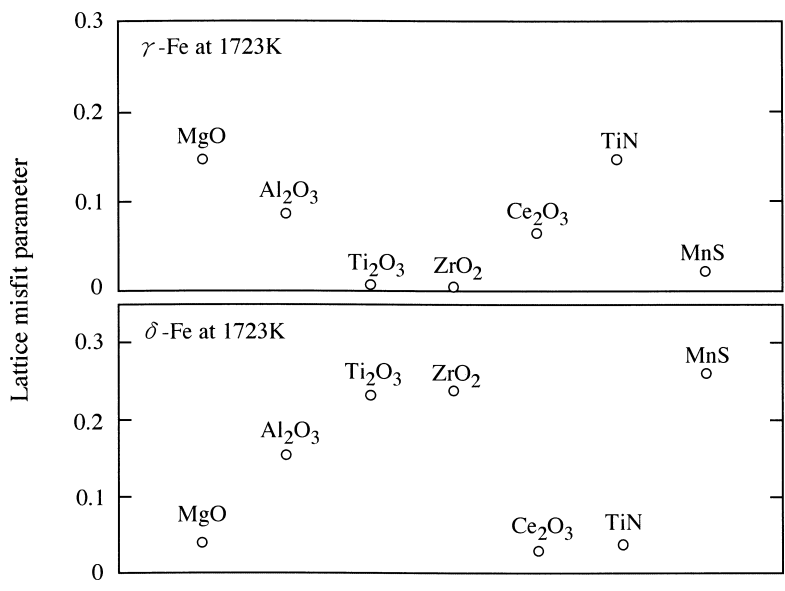

Fig. 2. Lattice misfit parameter between $\gamma$-Fe and oxide (upper diagram) and that between $\delta$-Fe and oxide (lower diagram).

that the size of globular cell is about $150 \mu \mathrm{m}$, independent of $N_{\mathrm{A}}$ in the range of $N_{\mathrm{A}}>100 \mathrm{~mm}^{-2}$ and irrespective of kind of oxides. It was found in the experiments where an $\mathrm{Fe}-10 \% \mathrm{Ni}$ alloy was cooled to $1400^{\circ} \mathrm{C}$ that the size of globular cell is strongly dependent on cooling rate. From the results shown in Fig. 1, it follows that the area fraction of globular cell is influenced by the chemical composition of oxide, but the size of globular cell is independent of the number of oxide and its chemical composition. The particle to particle spacing, $\lambda$, for $N_{\mathrm{A}}=100 \mathrm{~mm}^{-2}$ are estimated as $50 \mu \mathrm{m}$ from the relationship of $\lambda=1 / 2 N_{\mathrm{A}}^{-1 / 2}$. When this result is compared with the mean size $(150 \mu \mathrm{m})$ of globular cell, it can be concluded that most of the particles distributed uniformly are not used for the heterogeneous nucleation.

An $\mathrm{Fe}-0.50 \% \mathrm{C}-1 \% \mathrm{Mn}$ alloy was deoxidized with $\mathrm{Zr}$, Ce or $\mathrm{Mg}$ at $1600^{\circ} \mathrm{C}$ and cooled to $1400^{\circ} \mathrm{C}$ with $50 \mathrm{~K} \cdot \mathrm{min}^{-1}$, followed by rapid quenching, as shown in the lower diagram of Fig. 3. The $\bar{l}_{1} / \bar{\lambda}_{1}$ ratios (mean primary arm length/mean primary arm spacing) for $\mathrm{ZrO}_{2}$ and $\mathrm{Ce}_{2} \mathrm{O}_{3}$ are 2 and 4, respectively, but that for $\mathrm{MgO}$ is considerably high (10), indicating the development of the columnar dendrite. The reason that the columnar dendrite develops with an increase of dissolved $\mathrm{Mg}$ is not clear at present. One of the possible reason for this is that the $\mathrm{Mg}$ vaporization at crucible wall causes the steep thermal gradient.

The number of columnar dendrite was measured in a cross section of the ingot and then the number of columnar dendrite per unit area is plotted against the lattice misfit parameter between $\gamma$-Fe and oxide in the upper diagram of Fig. 3. It can be seen that the number of dendrite per unit area increases with decreasing the misfit parameter, suggesting that the order of heterogeneous nucleation potency for $\gamma$-phase solidification is explained by the lattice misfit parameter.

The contact angle, $\theta$, determined by the interfacial energy balance between oxide, $\gamma$-Fe and liquid $\mathrm{Fe}$ phases is represented by the following relation:

$$
\cos \theta=\left(\gamma_{\mathrm{MO} / \mathrm{Fe}(1)}-\gamma_{\mathrm{MO} / \mathrm{Fe}(\gamma)}\right) / \gamma_{\mathrm{Fe}(\mathrm{l}) / \mathrm{Fe}(\gamma)} \cdots
$$

Although the results shown in Fig. 3 can be explained by the lattice misfit parameter between oxide (MO) and $\gamma$-Fe,

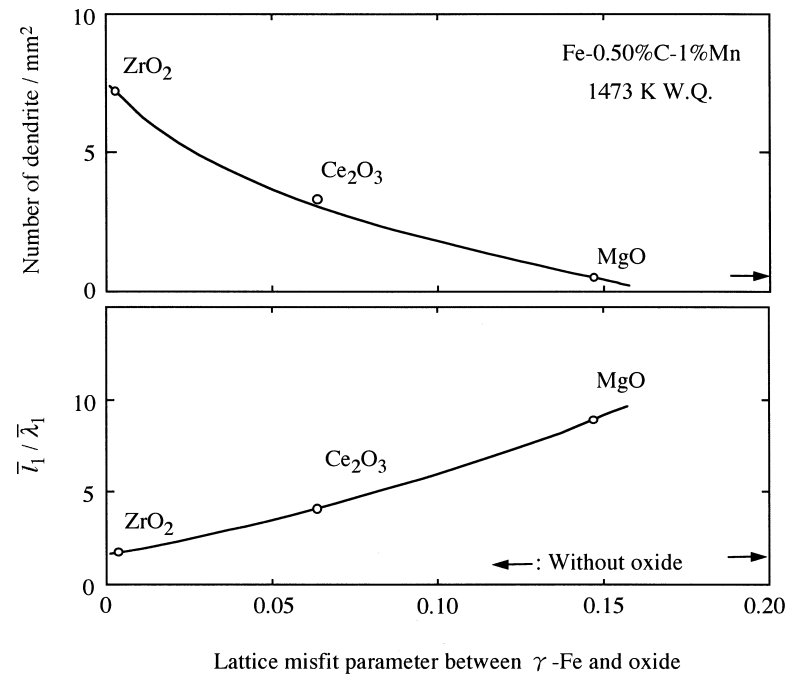

Fig. 3. Number of columnar dendrite and $\bar{l}_{1} / \bar{\lambda}_{1}$ ratio plotted against lattice misfit parameter between $\gamma$-Fe and oxide.

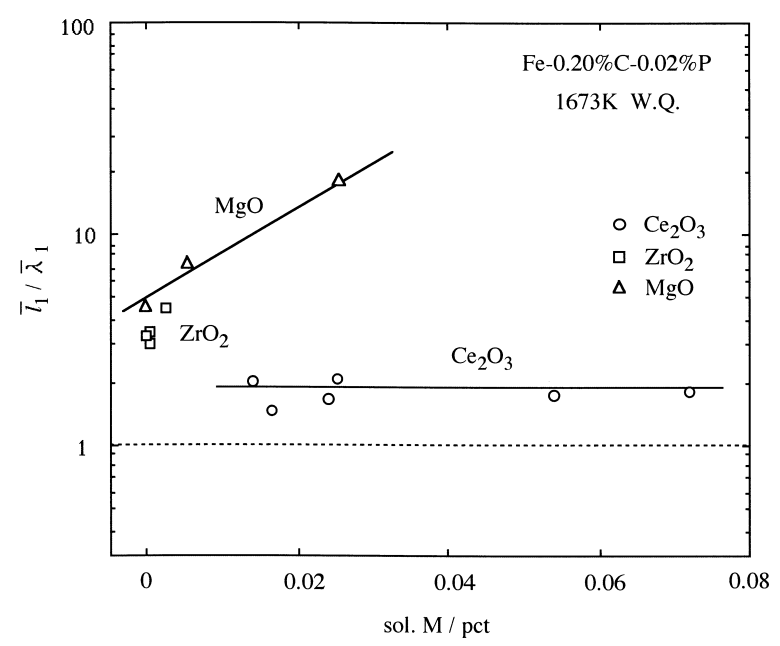

Fig. 4. Effect of dissolved $\mathrm{Ce}, \mathrm{Zr}$ of $\mathrm{Mg}$ content on solidification microstructure in $\mathrm{Fe}-0.20 \% \mathrm{C}-0.02 \% \mathrm{P}$ alloy.

these results should be properly interpreted from the values of contact angle. However, the $\gamma_{\mathrm{MO} / \mathrm{Fe}(1)}$ and $\gamma_{\mathrm{MO} / \mathrm{Fe}(\gamma)}$ values in the present study are not available and the $\gamma_{\mathrm{Fe}(1) / \mathrm{Fe}(\gamma)}$ value is supposed to be dependent on the content of deoxidant.

\subsubsection{Primary $\delta$-phase solidification}

The effect of dissolved solute $M(M=\mathrm{Ce}, \mathrm{Zr}$ and $\mathrm{Mg})$ on the solidification microstructure has been studied in the experiments ${ }^{5)}$ where an $\mathrm{Fe}-0.20 \% \mathrm{C}-0.02 \% \mathrm{P}$ alloy with primary $\delta$-phase solidification was deoxidized with $\mathrm{Ce}, \mathrm{Zr}$ or $\mathrm{Mg}$ at $1600^{\circ} \mathrm{C}$ and cooled to $1400^{\circ} \mathrm{C}$ at $50 \mathrm{~K} \cdot \mathrm{min}^{-1}$, followed by rapid quenching. The relationship between the $\bar{l}_{1} / \bar{\lambda}_{1}$ ratio and the content of dissolved $M$ is shown in Fig. 4. This ratio for Ce deoxidation is 2 independent of the dissolved Ce content and that for $\mathrm{Zr}$ deoxidation is 3 to 4 . However, that for $\mathrm{Mg}$ deoxidation increases with increasing the dissolved $\mathrm{Mg}$ content.

In a previous study, ${ }^{5)}$ it was observed that the mean primary and secondary dendrite arm spacings decrease with an increases in the dissolved Ce content. The present results coupled with previous one ${ }^{5)}$ suggest that the dendrite arm length also decreases with the dissolved Ce content. In a 


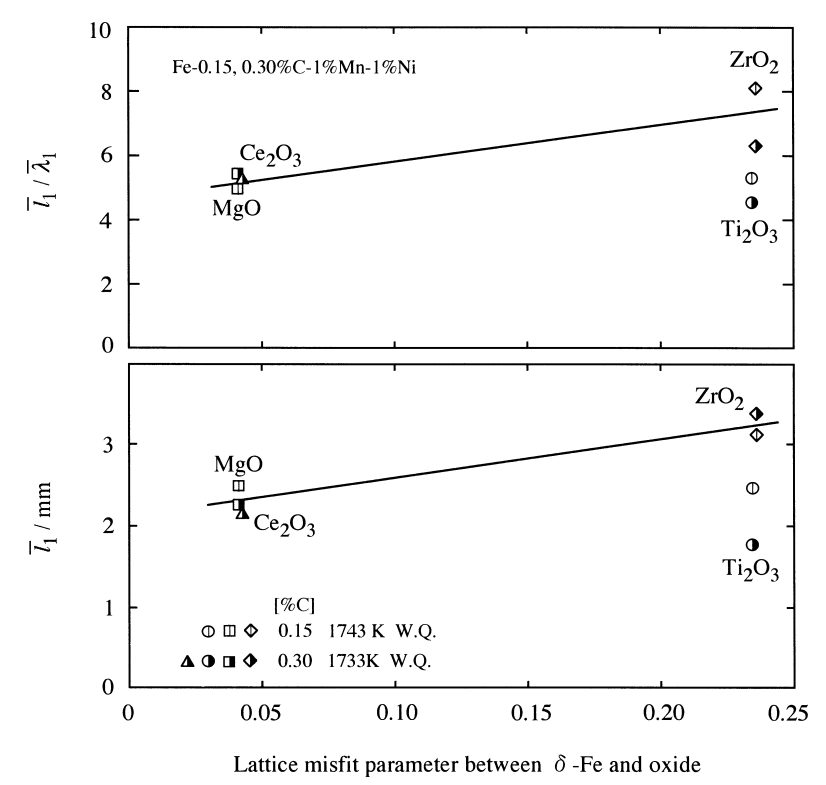

Fig. 5. $\bar{l}_{1} \bar{\lambda}_{1}$ ratio and $\bar{l}_{1}$ values plotted against lattice misfit parameter between $\delta$ - $\mathrm{Fe}$ and oxide in $\mathrm{Fe}-0.15 \% \mathrm{C}$, $0.30 \% \mathrm{C}-1 \% \mathrm{Mn}-1 \% \mathrm{Ni}$ alloy.

previous study, ${ }^{5)}$ it was found that the area fraction of equiaxed crystals increases with an increase of $\mathrm{Ce}_{2} \mathrm{O}_{3}$ or $\mathrm{CeS}$ particles. The lattice misfit parameter between $\delta$-Fe and $\mathrm{Ce}_{2} \mathrm{O}_{3}$ shown in the lower diagram of Fig. 2 is small and nearly the same as that between $\delta$-Fe and TiN in which the heterogeneous nucleation of $\delta$-Fe is experimentally confirmed. ${ }^{10)}$

An $\mathrm{Fe}-0.15$ or $0.30 \% \mathrm{C}-1 \% \mathrm{Mn}-1 \% \mathrm{Ni}$ alloy was deoxidized at $1600^{\circ} \mathrm{C}$ with $\mathrm{Ti}, \mathrm{Ce}, \mathrm{Mg}$ or $\mathrm{Zr}$ and cooled to $1470^{\circ} \mathrm{C}(\mathrm{C}=0.15 \%)$ and $1460^{\circ} \mathrm{C}(\mathrm{C}=0.30 \%)$ at $50 \mathrm{~K} \cdot$ $\mathrm{min}^{-1}$, followed by rapid quenching. These quenching temperatures determined by the cooling curves correspond to the start of the single $\gamma$-phase, namely, the temperatures in the single $\gamma$-phase just below the $\delta+\gamma$ and $\gamma+$ liquid two phases, respectively. For the purpose of revealing the solidification microstructure clearly, one $\% \mathrm{Ni}$ was added in this study.

The $\bar{l}_{1} / \bar{\lambda}_{1}$ ratio and $\bar{l}_{1}$ values are plotted against the lattice misfit parameter between $\delta$-Fe and oxide in Fig. 5, where $\bar{l}_{1}$ and $\bar{\lambda}_{1}$ represent the mean columnar dendrite arm length and its spacing, respectively. It can be seen that the $\bar{l}_{1} / \bar{\lambda}_{1}$ ratio decreases with decreasing the lattice misfit parameter, indicating that the equiaxed crystallization for $\mathrm{Ce}_{2} \mathrm{O}_{3}$ and $\mathrm{MgO}$ is more favorable than that for $\mathrm{ZrO}_{2}$. The reason that the data for $\mathrm{Ti}_{2} \mathrm{O}_{3}$ deviated from the line may be explained by the fact that number of primary deoxidation particles of $\mathrm{TiO}_{X}$ is considerably small and $\mathrm{TiO}_{X}$ particles together with $\mathrm{TiC}$ particles are observed in the interdendritic region.

The number of primary $\delta$-grains which correspond to the columnar dendrite was measured in a cross section of an $\mathrm{Fe}-0.15 \% \mathrm{C}-1 \% \mathrm{Mn}-1 \% \mathrm{Ni}$ alloy. This sample was obtained by quenching at $1500^{\circ} \mathrm{C}$ which is the liquid and $\delta$-Fe two phases region. The number density of $\delta$-grains is plotted against the lattice misfit parameter between $\delta$-Fe and oxide in the lower diagram of Fig. 6. It can be seen that the number of density of $\delta$-grains tends to increase with decreasing the misfit parameter, suggesting that the nucleation rate for
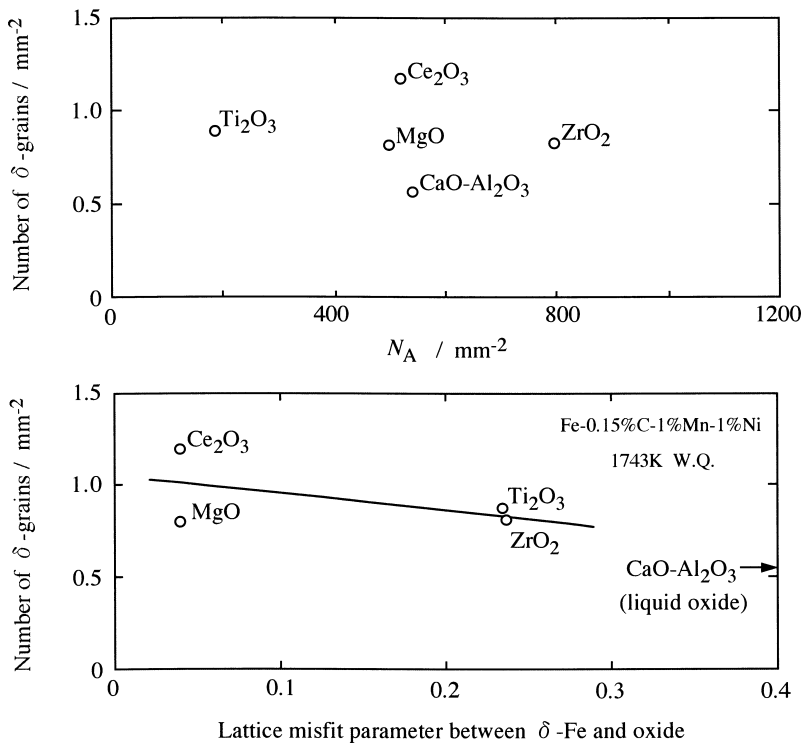

Fig. 6. Number of $\delta$-grains plotted against number of oxide particles (upper diagram) and misfit parameter between $\delta$-Fe and oxide (lower diagram) in $\mathrm{Fe}-0.15 \% \mathrm{C}-1 \% \mathrm{Mn}-1 \% \mathrm{Ni}$ alloy.

solidification become greater with increasing the nucleation potency represented by the misfit parameter. As shown in the upper diagram, the density of $\delta$-grains is independent of the number of oxide particles per unit area.

As mentioned previously in the explanation of the results in Fig. 3, the results in Fig. 6 are also explained by the following relation with respect to the contact angle between oxide, $\operatorname{Fe}(\delta)$ and $\operatorname{Fe}(1)$ three phases.

$$
\cos \theta=\left(\gamma_{\mathrm{MO} / \mathrm{Fe}(1)}-\gamma_{\mathrm{MO} / \mathrm{Fe}(\delta)}\right) / \gamma_{\mathrm{Fe}(1) / \mathrm{Fe}(\delta)}
$$

In order to have the high value of $\cos \theta$ in which the rate of heterogeneous nucleation is high, not only low value of $\gamma_{\mathrm{MO} / \mathrm{Fe}(\delta)}$ which corresponds to the lattice misfit parameter between MO and $\delta$-Fe, but also high value of $\gamma_{\mathrm{MO} / \mathrm{Fe}(\mathrm{l})}$ is desirable.

\subsection{Correspondence between Solidification Microstruc- ture and Initial Austenite Grain}

\subsubsection{Single-phase Solidification}

It is well known in a single-phase solidification that the columnar dendrites with their major axes aligned in the same direction correspond to the initial austenite or $\delta$-ferrite grain, if the grain growth is completely prohibited by pinning and/or solute drag. The correspondence between single-phase solidification microstructure and initial austenite grain is discussed in the following.

$\mathrm{Fe}-10 \% \mathrm{Ni}$ alloy: An $\mathrm{Fe}-10 \% \mathrm{Ni}$ alloy was deoxidized with $\mathrm{Ce}$ or $\mathrm{Zr}$ at $1600^{\circ} \mathrm{C}$ and cooled to $1400^{\circ} \mathrm{C}$ at $50 \mathrm{~K}$. $\mathrm{min}^{-1}$, followed by rapid quenching. Solidification microstructure of globular cell $\left(\bar{d}_{\mathrm{A}}\right)$ and the austenite grain size $\left(\bar{D}_{\mathrm{A}}\right)$ were measured as a function of $N_{\mathrm{A}}$ and dissolved $M(M=\mathrm{Ce}$ and $\mathrm{Zr})$ contents. The results are shown in Fig. 7 , indicating that the $\bar{D}_{\mathrm{A}} / \bar{d}_{\mathrm{A}}$ ratio is nearly unity in the range of $N_{\mathrm{A}}>150 \mathrm{~mm}^{-2}$ and [sol. M] $>0.02 \%$. Under the present cooling condition it is said that the austenite grain growth is completely prevented by pinning and solute drag effects, resulting in keeping the size of solidification microstructure.

Fe- $0.50 \% \mathrm{C}$ alloy: In the upper diagram of Fig. 8, the $\bar{D}_{\mathrm{A}}$ 

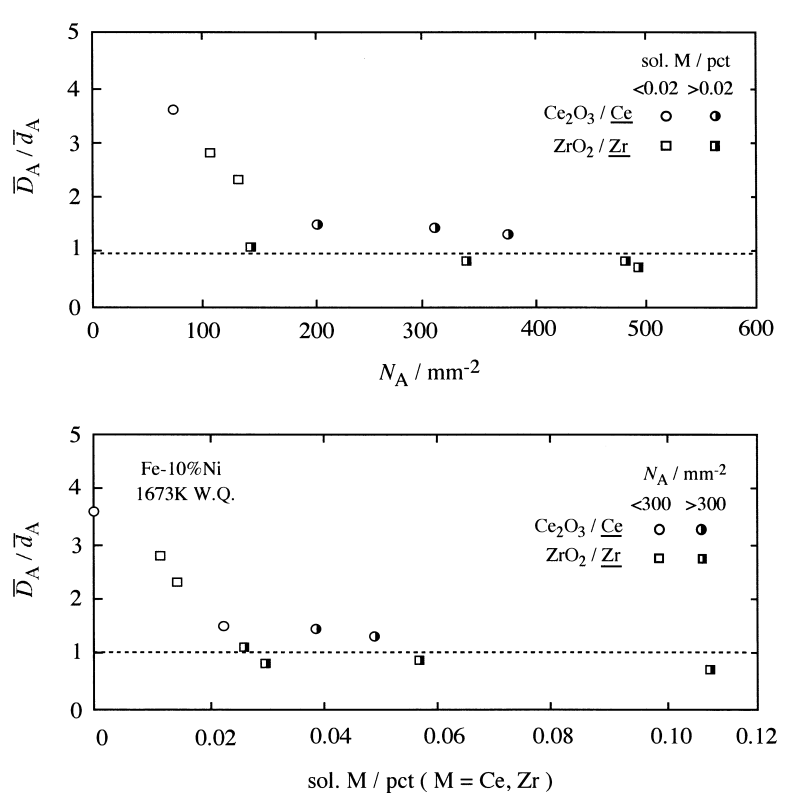

Fig. 7. Correspondence between solidification microstructure and austenite grain in $\mathrm{Fe}-10 \% \mathrm{Ni}$ alloy of single-phase solidification.

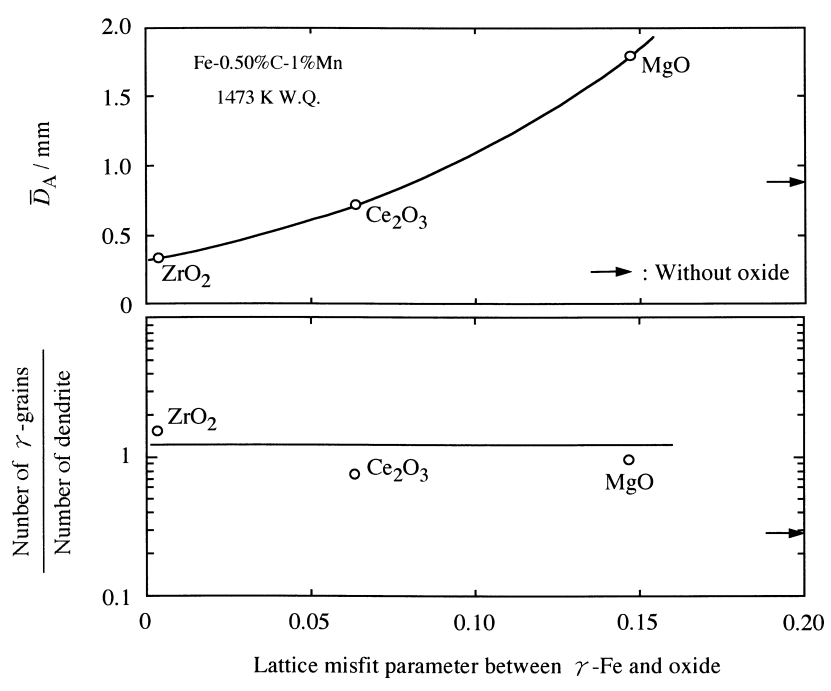

Fig. 8. $\quad \bar{D}_{\mathrm{A}}$ and Number of $\gamma$-grains/number of $\delta$-grains ratio plotted against lattice misfit parameter between $\gamma$-Fe and oxide in $\mathrm{Fe}-0.50 \% \mathrm{C}-1 \% \mathrm{Mn}$ alloy.

values are plotted against the lattice misfit parameter between $\gamma$-Fe and oxide in an $\mathrm{Fe}-0.50 \% \mathrm{C}-1 \% \mathrm{Mn}$ alloy, which was cooled to $1200^{\circ} \mathrm{C}$ at $50 \mathrm{~K} \cdot \mathrm{min}^{-1}$. It is seen that the $\bar{D}_{\mathrm{A}}$ values decrease with decreasing the misfit parameter. The reason that the $\bar{D}_{\mathrm{A}}$ value for $\mathrm{MgO}$ greater than that obtained without deoxidation particles (a melt was held for 30 min after $\mathrm{Al}$ addition) can be explained by the effect of dissolved $\mathrm{Mg}$ on the development of columnar dendrite as mentioned previously. If it is assumed that the austenite grain growth is completely prohibited by particle pinning, this finding can be explained by the fact that in single-phase solidification the solidification microstructure which is influenced by the degree of the lattice misfit parameter between $\gamma$-Fe and oxide corresponds to the initial austenite grain.

This was confirmed by the plot shown in the lower diagram of Fig. 8, in which the ratio of the number of $\gamma$-grains
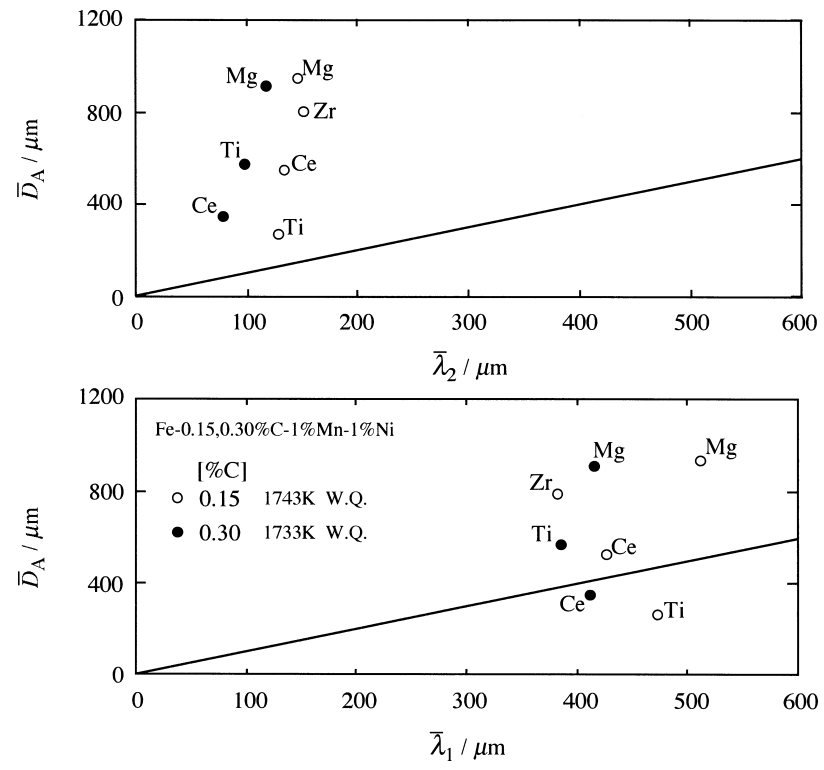

Fig. 9. Relationships between $\bar{D}_{\mathrm{A}}$ and $\bar{\lambda}_{2}$ (upper diagram) and that between $\bar{D}_{\mathrm{A}}$ and $\bar{\lambda}_{1}$ (lower diagram) in Fe-0.15, $0.30 \% \mathrm{C}-1 \% \mathrm{Mn}-1 \% \mathrm{Ni}$ alloys.

to the number of $\delta$-grains per unit area is plotted against the lattice misfit parameter. These ratios obtained by $\mathrm{Zr}, \mathrm{Ce}$ and $\mathrm{Mg}$ deoxidations are nearly unity and independent of the misfit parameter. It can be concluded that in single phase solidification the solidification microstructure is influenced by the chemical composition of oxide with different nucleation potency, but the solidification microstructure corresponds to the austenite grains under the complete inhibition of grain growth.

\subsubsection{Two-phases Solidification}

In this section the effects of oxide particles on the heterogeneous nucleation site for the $\delta$ to $\gamma$ transformation and the austenite grain growth are studied in an $\mathrm{Fe}-0.15 \%$ or $0.30 \% \mathrm{C}-1 \% \mathrm{Mn}-1 \% \mathrm{Ni}$ alloy. The deoxidation particles dispersed uniformly in microsegregation domain are used for the $\gamma$-phase nucleation in $\delta$-phase matrix in an $\mathrm{Fe}-\mathrm{C}$ $(<0.1 \%)$ alloy. In the case of $\mathrm{Fe}-\mathrm{C}(0.15$ or $0.30 \%)$ alloy, however, the particles located at $\delta /$ liquid interface where the peritectic reaction occurs are only used for the heterogeneous nucleation site. The place at which the peritectic reaction occurs approaches low fraction of solid with decreasing carbon content. It should be noted that the correspondence between the interdendritic region and austenite grain boundaries is different at hypo and hyper peritectic regions.

The mean austenite grain size, $\bar{D}_{\mathrm{A}}$, obtained in an $\mathrm{Fe}-$ 0.15 or $0.30 \% \mathrm{C}-1 \% \mathrm{Mn}-1 \% \mathrm{Ni}$ alloy which was quenched at $1470^{\circ} \mathrm{C}(0.15 \% \mathrm{C})$ and $1460^{\circ} \mathrm{C}(0.30 \% \mathrm{C})$ is plotted against the mean values for the secondary dendrite arm spacing, $\bar{\lambda}_{2}$, and the primary dendrite arm spacing, $\bar{\lambda}_{1}$, in the upper and lower diagrams of Fig. 9, respectively. It can be seen that the $\bar{D}_{\mathrm{A}}$ values vary considerably from 200 to $1000 \mu \mathrm{m}$, but the $\bar{\lambda}_{1}$ and $\bar{\lambda}_{2}$ values are nearly constant.

The aspect ratio of austenite grain and the geometric standard deviation in log-normal distribution of grain size, $\ln \sigma$, are plotted against the $\bar{l}_{1} / \bar{\lambda}_{1}$ ratio in the upper and lower diagrams of Fig. 10, respectively. It can be seen from 


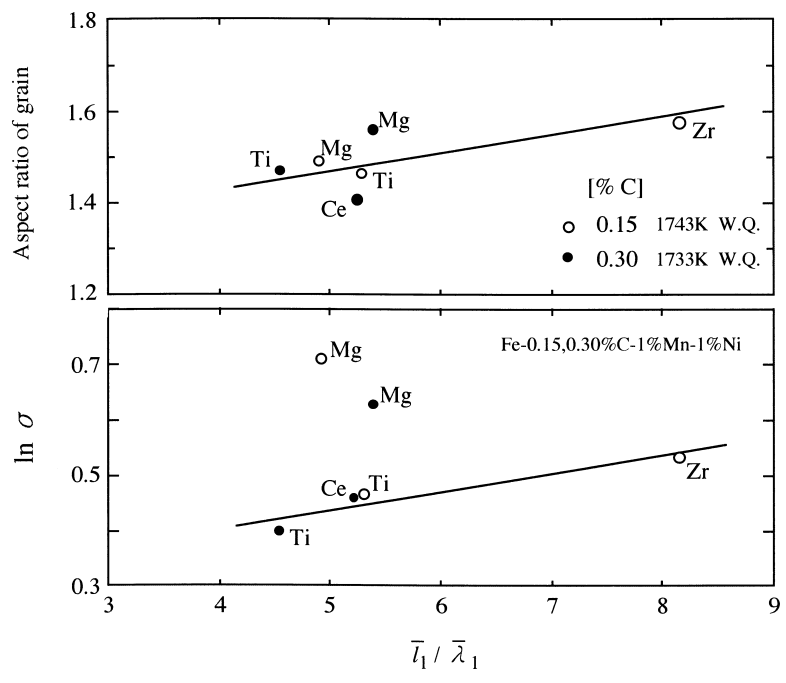

Fig. 10. Aspect ratio of grain and $\ln \sigma$ plotted against $\bar{l}_{1} / \bar{\lambda}_{1}$ in $\mathrm{Fe}-0.15,0.30 \% \mathrm{C}-1 \% \mathrm{Mn}-1 \% \mathrm{Ni}$ alloy.

the upper diagram that the morphology of austenite grain is more or less equiaxed, while that of the $\delta$-grains is columnar. This is clear from the comparison between the aspect of grain and $\bar{l}_{1} / \bar{\lambda}_{1}$ ratio. The $\bar{l}_{1} / \bar{\lambda}_{1}$ ratio in the $\mathrm{Zr}$ deoxidation is significantly higher than those in other deoxidations. This is probably due to the fact that the morphology of $\delta$ grains is strongly influenced by the content of dissolved deoxidant, in particular, the dissolved $\mathrm{Zr}$ content. In the $\mathrm{Mg}$ deoxidation experiment dissolved $\mathrm{Mg}$ content was minimized by holding at $1600^{\circ} \mathrm{C}$ for $10 \mathrm{~min}$ to vaporize. It is seen from the lower diagram that the spread of grain size distribution is greater in the $\mathrm{Mg}$ deoxidation. Although the reason for this is not certain, it was experimentally observed that the $\ln \sigma$ value in the $\mathrm{Mg}$ deoxidation increases with an increase of dissolved $\mathrm{Mg}$ content.

The grain size distributions observed in an $\mathrm{Fe}-0.15 \% \mathrm{C}-$ $1 \% \mathrm{Mn}-1 \% \mathrm{Ni}$ alloy are shown in Fig. 11. It is seen that the grain size distribution in the $\mathrm{Mg}$ deoxidation is bi-modal and the peak observed in larger grain size is due to the effect of dissolved $\mathrm{Mg}$. If dissolved $\mathrm{Mg}$ is removed by evaporation and its content approaches zero, no bi-modal distribution was observed. The mode value of the grain size distribution observed in the Ti deoxidation is smaller compared with those observed in other deoxidations. It was found in the $\mathrm{Ti}$ deoxidation experiments by using the microprobe analysis that $\mathrm{TiO}_{x}$ and $\mathrm{TiC}$ particles are precipitated in the interdendritic space in an $\mathrm{Fe}-0.15$ or $0.30 \% \mathrm{C}$ alloy, not in an $\mathrm{Fe}-0.05 \% \mathrm{C}$ alloy. It is considered that these precipitates effectively pin the austenite grain growth and/or become the candidate for the heterogeneous nucleation site for the $\delta$ to $\gamma$ transformation.

The mean austenite grain sizes observed in the $\mathrm{Ti}, \mathrm{Zr}$, $\mathrm{Ce}, \mathrm{Mg}$ and $\mathrm{Ti} / \mathrm{Mg}$ deoxidations are plotted against the lattice misfit parameter between $\gamma$-Fe and oxide in Fig. 12, together with the results obtained in the $\mathrm{Ca}$ deoxidation and without deoxidation. It is clear that the $\bar{D}_{\mathrm{A}}$ values decrease with a decrease in the misfit parameter. The results shown in Fig. 12 were obtained in the interrupted experiment where a sample was quenched immediately at the highest temperature of the austenite single phase. Therefore, it is reasonable to assume that the austenite grain growth is

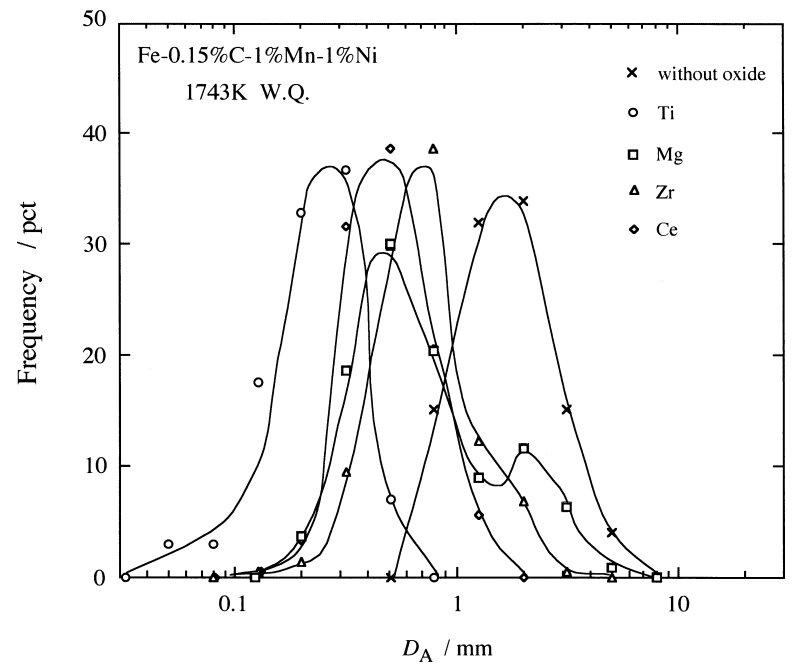

Fig. 11. Grain size distribution in $\mathrm{Fe}-0.15 \% \mathrm{C}-1 \% \mathrm{Mn}-1 \% \mathrm{Ni}$ alloy deoxidized with various deoxidants.

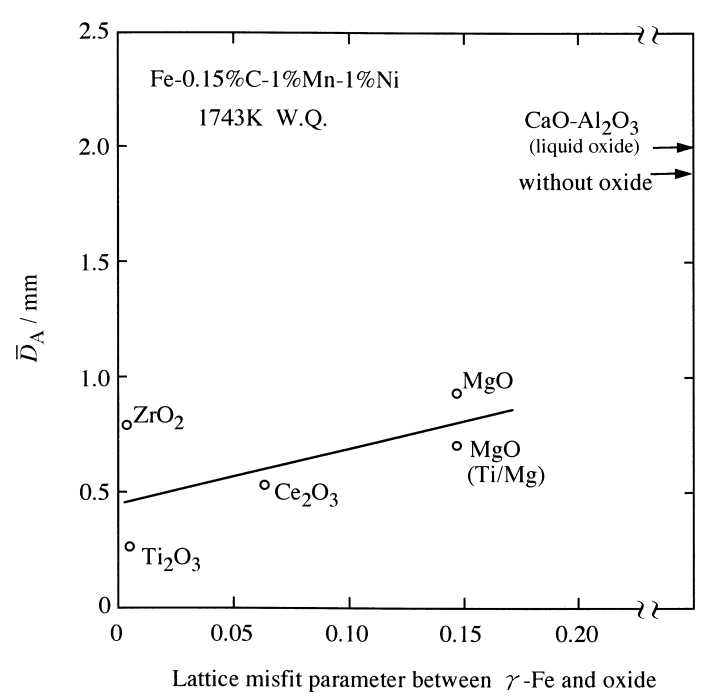

Fig. 12. $\bar{D}_{\mathrm{A}}$ plotted against lattice misfit parameter between $\gamma$-Fe and oxide.

pinned during the cooling by the presence of coexisting $\delta$ phase in the $\delta$ and $\gamma$ two phases region. If the number density of $\gamma$-grains during the two phases is constant, it is considered that the $\bar{D}_{\mathrm{A}}$ values shown in Fig. 12 correspond to the initial number density of $\gamma$-grains after $\delta / \gamma$ transformation. In this study the heterogeneous nucleation rate of $\gamma$ phase for different oxides are represented by the lattice misfit parameter between $\gamma$-Fe and oxide.

In order to study the effect of oxide particles on the grain growth inhibition, the $\bar{D}_{\mathrm{A}}$ values are plotted against the Zener pinning force, $\mathrm{Zp}$, which is given by

$$
Z_{\mathrm{p}}=3 \sigma \cdot V \cdot f_{\mathrm{V}} / \bar{d}
$$

where $\sigma$ is the grain boundary energy $\left(6 \times 10^{-7} \mathrm{~J} \cdot \mathrm{mm}^{-2}\right)$, $V$ is the molar volume of $\mathrm{Fe}\left(7 \times 10^{3} \mathrm{~mm}^{3} \cdot \mathrm{mol}^{-1}\right)$, and $f_{\mathrm{V}}$ and $\bar{d}$ are the volume fraction and the mean particle diameter, respectively.

It can be seen from Fig. 13 that the $\bar{D}_{\mathrm{A}}$ values decrease with an increase in the $Z_{\mathrm{p}}$ value, indicating that the order of the $\bar{D}_{\mathrm{A}}$ values observed in different deoxidations can be explained by the different degree of the pinning force. 


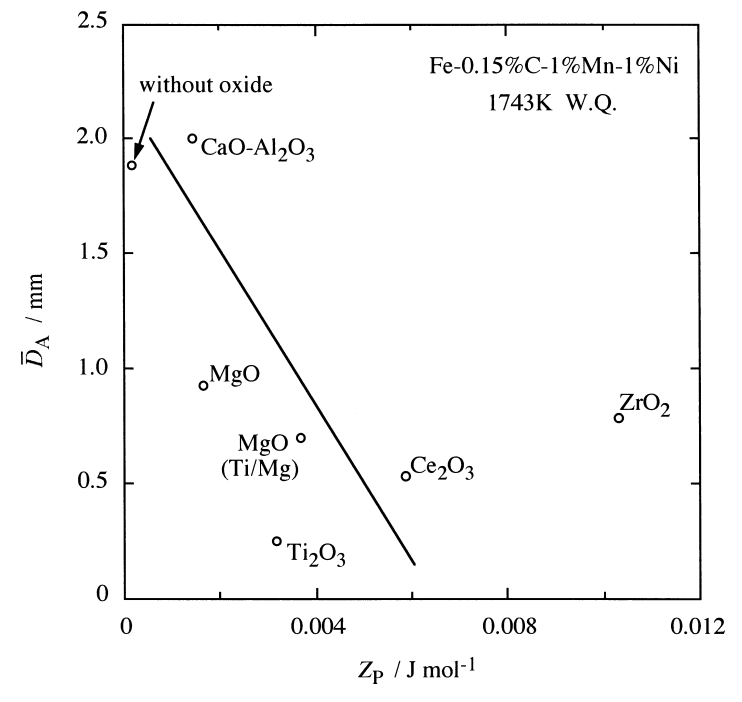

Fig. 13. $\bar{D}_{\mathrm{A}}$ plotted against Zener pinning force in $\mathrm{Fe}-0.15 \% \mathrm{C}-$ $1 \% \mathrm{Mn}-1 \% \mathrm{Ni}$.

Therefore, the observed behavior of the grain size distribution shown in Fig. 11 can be interpreted by both nucleation rate and grain growth inhibition.

The number of columnar dendrite per unit area in a cross section of an $\mathrm{Fe}-0.15 \% \mathrm{C}-1 \% \mathrm{Mn}-1 \% \mathrm{Ni}$ alloy was measured in the experiments quenched at $1500^{\circ} \mathrm{C}$ and that of the austenite grain per unit area was measured in the experiments quenched at $1470^{\circ} \mathrm{C}$. The ratios of the number of $\gamma-$ grains to that of $\delta$-grains per unit area are plotted against the lattice misfit parameter between $\gamma$-Fe and oxide in the upper diagram of Fig. 14. The finding that this ratio increases with a decrease in the misfit parameter indicates that the nucleation rate is higher with increasing the nucleation potency. In other words, more than one nucleation event per one $\delta$-grain occurs at the $\delta$ /liquid interface.

The results in the lower diagram of Fig. 14 should be explained by the following relation with respect to the contact angle between oxide, $\operatorname{Fe}(\delta)$ and $\operatorname{Fe}(\gamma)$ three phases.

$$
\cos \theta=\left(\gamma_{\mathrm{MO} / \mathrm{Fe}(\delta)}-\gamma_{\mathrm{MO} / \mathrm{Fe}(\delta)}\right) / \gamma_{\mathrm{Fe}(\delta) / \mathrm{Fe}(\gamma)}
$$

In order to have the high rate of $\gamma$-phase nucleation at $\delta /$ liquid interface, namely, high value of $\cos \theta$, not only low value of $\gamma_{\mathrm{MO} / \mathrm{Fe}(\gamma)}$ which corresponds to the lattice misfit parameter between $\mathrm{MO}$ and $\gamma$-Fe, but also high value of $\gamma_{\mathrm{MO} / \mathrm{Fe}(\delta)}$ is necessary.

In can be seen from the upper diagram that this ratio does not increase with an increase in the number of particles per unit area, $N_{\mathrm{A}}$, indicating that the nucleation rate of $\gamma$-phase is not influenced by the number of nucleation site.

\section{Conclusions}

The effect of deoxidation particles on the $\gamma$-or $\delta$-phase solidification microstructure has been studied in $\mathrm{Fe}-10 \% \mathrm{Ni}$ and $\mathrm{Fe}-0.50 \%-1 \% \mathrm{Mn}$ alloys. It was found that solidifica-
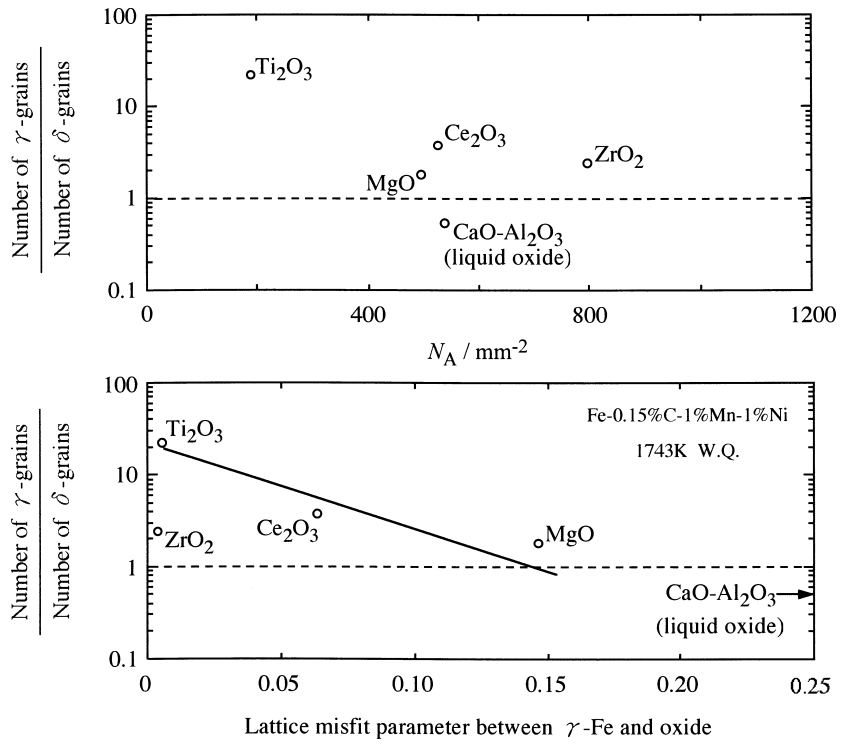

Fig. 14. Number of $\gamma$-grains to number of $\delta$-grains per unit area plotted against $N_{\mathrm{A}}$ (upper diagram) and lattice misfit parameter between $\gamma$-Fe and oxide (lower diagram).

tion microstructure for a given cooling rate is influenced by the chemical composition of oxide and the degrees of equiaxed crystallization in $\gamma$ - and $\delta$-phase solidifications are well related to the lattice misfit parameter between $\gamma$-Fe and oxide and that between $\delta$-Fe and oxide, respectively.

The correspondence between solidification microstructure and initial austenite grains has been studied by using the interrupted solidification method coupled with the grain growth inhibition by pinning. As a result, under the condition that the grain growth is completely retarded by pinning and/or solute drag, it was confirmed that initial austenite grains correspond to the solidification microstructure in $\gamma$ phase single solidification. In two-phases solidification of an $\mathrm{Fe}-0.15$ or $0.30 \% \mathrm{C}$ alloy, the correspondence between solidification microstructure and initial austenite grains in the presence of oxide particles is explained by the nucleation potency for the $\delta$ to $\gamma$ transformation and/or the grain growth inhibition.

\section{REFERENCES}

1) O. Grong and D. K. Matlock: Inter. Met. Rev, 31 (1986), 27.

2) A. O. Kluken, O. Grong and G. Rorvik: Metal. Trans. A, 21A (1990), 2047.

3) K. Sakata and H. Suito: Metall. Mater. B, 30B (1999), 1053.

4) K. Sakata and H. Suito: Metall Mater. A, 31A (2000), 1213.

5) M. Guo and H. Suito: ISIJ Int., 39 (1999), 722.

6) M. Guo and H. Suito: ISIJ Int., 39 (1999), 1289.

7) H. Suito: 182nd-183rd Nishiyama Memorial Seminar, Technology for Control of Nonmetallic Inclusions and Production of Clean Steels, ISIJ, Tokyo, (2004), 29.

8) G. V. Pervushin and H. Suito: ISIJ Int., 41 (2001), 728.

9) H. I. Aronson, C. Laird and K. R. Kinsman: Phase Transformations, ASM, Metals Park, OH, (1970), 313.

10) T. Koseki and H. Inoue: J. Jpn. Inst., Met., 65 (2001), 644. 